\title{
The Quality of Income of Manufacturing Companies in Indonesia Based on the Tax Planning and Deferred Paid Tax
}

\author{
Chalarce Totanan \\ Tadulako University \\ chalarce@untad.ac.id
}

\author{
Yamin \\ Tadulako University \\ ninayamin@untad.ac.id
}

\author{
Muhammad Afdhal S \\ Tadulako University \\ afdhaldhalle@gmail.com
}

\begin{abstract}
This study aims to analyze the quality of income based on the tax planning and deferred tax expense with proxy discretionary accruals. this research covers 2007 until 2016 period of time. this research data are obtained from annual reports of manufacturing companies available on the official website of indonesia stock exchange. the hypothesis testing technique uses multiple linear regression analysis. the result of $f$ test analysis shows that the tax planning and deferred tax expense have significant effect to earning quality. meanwhile, $t$ test results prove that tax planning has a significant effect on earning quality and deferred tax expense does not affect the quality of earnings.
\end{abstract}

Keywords: Deferred Tax Expense, Discretionary Accrual, Earnings Quality,

\section{INTRODUCTION}

Based of quality information are transparency and accountability, profit as information in financial statements for quality must meet both requirements [1]. In addition to accountability and transparency, in order for the earning information to be reliable, profits need to be persistent or sustainable. Therefore, persistent earnings are relevant to the existence of the company [2]. In the long run, management may perform accounting practices on the rate of profit, but it will result in a decrease in the quality of earnings in the financial statements, so that it can lead to errors in decision making [3]. According to Barus and Kiki, the quality of earning information also cannot be a reflection of the quality of profit because of the possibility of earning management. This is in line with Soon [4], the opinion that management's intervention can hide the shortcomings of the company's performance. This implies the engineering of profit-quality impact and will result in a negative public response [5]. This study aims to see the quality of profits of manufacturing companies listed on the Indonesia Stock Exchange based on the tax planning and deferred tax expense by adding data observation period as suggested by Dyreng, Hanlon, \& Maydew [6].

\section{METHOD}

This study used secondary data in the form of financial statements 2007-2016 from manufacturing companies listed on the Stock Exchange with 23 sample with 10 years' observation. Data obtained through ww.idx.co.id Target population were all manufacturing companies listed on the Indonesia Stock Exchange (BEI). Objects in this study were tax planning and deferred tax as an independent variable and profit quality as a dependent variable. To identify firms that do tax planning, this study used the effective cash tax rate (CashETR) developed by Dyreng et. al. [7] To calculate deferred tax expense, this study referred to book-tax differences (BTD) or differences in accounting profit to fiscal profit, on the basis of measurements made by [8]. All variables in research were brought into multiple linear regression.

\section{RESULT}

\section{Tax Planning, Deferred Tax Expense and Profit} Quality.

The way to choose is with certain accounting policies so that the amount of profit displayed in the financial statements will be different from the actual situation [9]. If management has taken a policy in earning management, it will result in the discretionary accrual. Discretionary accruals are accruals that may change in accordance with management policies, such as consideration of determining the economic life of fixed assets or the consideration of the selection of depreciation methods [10]. In addition to raising corporate value, discretionary accrual by management is also influenced by management positions as agents of principals. Agents need a strategy to satisfy a principal. Therefore, a contract between the principal and management is required, and the agreement is expected to maximize the principal utility and guarantee the management to receive rewards from the results of the company's management activities in the form of material and non-material such as position in the company [11]. Therefore, the first hypothesis (H1) in this study is:

H1: Tax planning and deferred tax expenses have significant effect on earning quality.

\section{Tax Planning and Profit Quality}

The managers who want a low tax payment tend to be discretionary in order to report low earnings. On the one hand, managers will try to report increased profits to raise company value. This means that when companies 
want to publish good financial performance to the public, then managers will report relatively large and increased profits in each period [12]. On the other hand, managers will do tax planning to reduce the amount of tax obligations, so that taxation obligations will be lower than that should be paid by the company. [13]-[14]. stated that there is an influence of tax planning on earnings management, thus indicating the low quality of earned profits. However, Syanthi, Sudarma, \& Saraswati [15] stated that tax planning has no effect on earnings management practices, which influences the quality of earnings. This means that previous research has not yielded consistent results. Therefore, it still needed further research for different subject to see the effect of tax planning with earnings quality. Based on the above description, the second hypothesis in this study formulated as follows:

H2: Tax planning has a significant effect on earnings quality.

\section{Deferred Tax Expense and Profit Quality}

Theoretically, quality information is transparent and accountable. It means if the profit figure is suspected as the result of engineering from the management policy, then the profit figure is not qualified. Earnings that are judged to be a incompatible quality with accounting principles will have consequences for public response, especially for economic decision making. The management is still doing the policy. This is done because the earning figure is correlated with the bonus or compensation to be received by management [16]. Some large corporations have proven to have discretionary profits with the aim of formulating tax planning as tax avoidance without violating the law by exploiting the opportunity to minimize the amount of tax burden payable. The goal is to complete the investment to build a new factory (business expansion) and later the flow of funds is used to increase corporate profits [17]. Therefore, the third hypothesis of this article is: H3: Deferred tax expense affects earning quality.

\section{Testing}

\section{Classical Assumption Testing and Testing Regression Equations}

The regression equation is considered good if it meets the regression assumptions. The regression assumption to be seen is the assumption of normal distribution error, free multicollinearity and no heteroscedasticity. The multiple linear regression equation as: $\mathrm{Y}=0,525+$ $0,165 \mathrm{X} 1+0,071 \mathrm{X} 2$. This means that the quality of earnings without tax planning and deferred taxes is positive and significant. The value of correlation coefficient (Multiple R) is 0.222 or low because it is at the level of relationship between $0.200-0.399$ of low value [18] and coefficient of determination (R Square) is 0,049 is very low. It means $95 \%$ quality of earnings is influenced by other variables, and variable of tax planning and tax deferred only influences 5\%. This study proves that the quality of information is more influenced by transparency and accountability.

\section{Hypothesis Testing Results}

Based on the test results, the value of Fcount amounted to 5.389 and $F$ table value of 3.039 with the criterion if the value $F$ count $>F$ table means that both tax planning and deferred tax burden significantly influenced the quality of profit, the first hypothesis could be accepted. It means $95 \%$ confidence level is one of the variables of tax planning and deferred tax on earning quality in manufacturing companies in Indonesia.

Based on the value of regression coefficient of tax planning of 0.165 and deferred tax burden of 0.071 , both are positive even though quite low according [19]. The number is significant that there is an influence of tax planning and deferred tax expense to earning quality.

This test was performed to test whether the proposed hypothesis is accepted or rejected. The hypothesis is accepted or rejected by referring to the criteria of test if $t$ arithmetic $>t$-table, then the null hypothesis is rejected, and vice versa if $t$-count $<t$-table means hypothesis is accepted. The test results showed that $t$ test statistical calculation of tax planning and deferred tax burden were included in the regression model as follows:

The result of $t$ test of tax planning to earning quality showed that tcount 2,429>ttable equalt to 1,971 and significance value equalt to $0,016<0,05$ (significance $a=$ $5 \%$ ). The resulting influence is marked positive; it indicates that partially tax planning gives effect to earning quality. The value of the partial determinant coefficient (r2) is 0.166 .

The result of $t$ test of deferred tax expense to earning quality showed that the value of tcount is $1,912<$ ttabel equalt to 1,971 and significance value equalt to $0,057>$ 0,05 (significance $a=5 \%$ ). This indicates that partially deferred tax expense does not give effect to earnings quality. By these results, the third hypothesis that the deferred tax burden has significant effect is not accepted.

\section{CONCLUSION}

Based on the results of this study, it could be concluded that the value of earnings quality with a persistent discretionary accrual proxy to make current discretionary accruals can be used to predict future discretionary accruals. The results of this hypothesis testing supports the statement that if the tax planning is positive, the quality of profit measured by discretionary accrual will be good. It can be used as an indicator of future earnings. Recommendations for further research are to expand the study population so that research results can be obtained with a higher level of generalization. Likewise, further research may add variables on the behavioral aspect that becomes the motivation of the perpetrator in the discretionary aspects of accrual primary associated with the tax aspects as part of fiscal policy. 


\section{REFERENCES}

[1] Afriyanto, Pungki. Pengaruh Perbedaan Antara Laba Akuntansi dan Laba Fiskal Terhadap Persistensi Laba (Studi Empiris Pada Perusahaan Manufaktur Yang Terdaftar di Bursa Efek Indonesia). Indonesian Publication Index. 2013.

[2] Astutik Puji Eka Ratna dan Mildawati Titik. Pengaruh Perencanaan Pajak Dan Beban Pajak Tangguhan Terhadap Manajemen Laba. Surabaya: Jurnal Ilmu dan Riset Akuntansi : Volume 5, Nomor 3, Maret 2016. 2016.

[3] Barus Caroline Andreani dan Setiawati Kiki. Pengaruh Asimetri Informasi, Mekanisme Corporate Governance, dan Beban Pajak Tangguhan Terhadap Manajemen Laba. Medan: Jurnal Wira Ekonomi Mikroskil Volume 5, No 1. 2015.

[4] Dechow, P. M. Accounting Earnings and Cash Flows as Measures of Firm Performance: The Role of Accounting Accruals. Journal of Accounting and Economics 17, hlm. 3-42. 1995.

[5] Dyreng D. S., M. Hanlon, dan L. E. Maydew. Long-Run Corporate Tax Avoidance. The Acc. Review 83. 61-82. 2008.

[6] Hanlon Michelle. The Persistence and Pricing of Earnings, Accruals, and Cash Flows When Firms Have Large Book-Tax Differences. The Accounting Review Vol. 80, No. 1 pp. 137-166. 2005.

[7] Himawan. Kompas.com/ Anak Usaha Sinarmas Mendapatkan "Tax Holiday" 8 Tahun. Diakses tanggal 8 Januari 2017. 2015

[8] Jensen Michael C. Self-Interest, Altruism, Incentives, and Agency Theory. Journal of Applied Corporate Finance, Vol. VII, No. 2 and Harvard University Press. 1994.

[9] Khotimah Husnul. Pengaruh Perencanaan Pajak Terhadap Manajemen Laba. Jakarta: E S E N S I Jurnal Bisnis dan Manajemen Vol.4 No. 2. 2014.

[10] Lamora Starga P, Vince dan Kamaliah. Pengaruh Kepemilikan Manajerial, Kepemilikan Institusional Dan Kepemilikan Keluarga Terhadap Manajemen Laba (Earning Management) Pada Perusahaan Berkepemilikan Ultimat Yang Terdaftar Di BEI. E-Journal Universitas Riau. 2012.
[11] Persada Eka Aulia dan Martani Dwi. Analisis Faktor Yang Mempengaruhi Book Tax Gap Dan Pengaruhnya Terhadap Persistensi Laba. Jakarta: Jurnal Akuntansi dan Keuangan Indonesia Volume 7 - No. 2. 2010.

[12] Philips, J., M. Pincus, and S. Rego. Earnings Management: New Evidence Based on Deferred Tax Expenses. 2003.

[13] Pindiharti, Dewi. Pengaruh Aktiva Pajak Tangguhan, Beban Pajak Tangguhan dan Akrual Terhadap Earnings Management. Institutional Repository UIN Syarif Hidayatullah Jakarta. 2011.

[14] Putra Asmara. Manajemen Laba: Perilaku Manajemen Opportunistic Atau Realistic?. Univ. Udayana Vol. 6, No. 1. 2011.

[15] Rudra Titas. Does IFRs Influence Earnings Management? Evidence from India. Jour. of Management Research Vol. 4. 2012.

[16] Stevens E. Douglas dan Thevaranjan Alex. Ethics and Agency Theory: Incorporating a Standard for Effort and an Ethically Sensitive Agent. ssrn.com. 2003.

[17] Sumomba Ranty Christina dan Hutomo Sigit YB. Pengaruh Beban Pajak Tangguhan Dan Perencanaan Pajak Terhadap Manajemen Laba. Yogjakarta: Jurnal Kinerja Volume 16, No.2, Th. 2012 Hal. 103-115. 2015.

[18] Syanthi Trisna Nila, Sudarma Made dan Saraswati Erwin. Dampak Manajemen Laba Terhadap Perencanaan Pajak dan Persistensi Laba. Malang: Jurnal Ekonomi dan Keuangan. 2012.

[19] Widiatmoko Jacobus dan Mayangsari Ika. The Impact Of Deferred Tax Assets, Discretionary Accrual, Leverage, Company Size And Tax Planning On Earnings Management Practices. Semarang: Jurnal Dinamika Manajemen, 7 (1) 2016, 22-31. 2016. 